\title{
Initial Cancer Diagnosis Date
}

National Cancer Institute

\section{Source}

National Cancer Institute. Initial Cancer Diagnosis Date. NCI Thesaurus. Code C157121.

The date of the initial cancer diagnosis. 